\title{
The Patterns of Tungiasis in Araruama Township, State of Rio de Janeiro, Brazil
}

\section{Raimundo Wilson de Carvalho $/{ }^{+}$, Adilson Benedito de Almeida, Silvia Cristina Barbosa- Silva, Marinete Amorim, Paulo César Ribeiro*, Nicolau Maués Serra-Freire/ ${ }^{++}$}

\author{
Laboratório de Ixodides, Departamento de Entomologia, Instituto Oswaldo Cruz-Fiocruz, Av. Brasil 4365 sala 214, 21045-900 \\ Rio de Janeiro, RJ, Brasil *Instituto de Biologia do Exército, Rio de Janeiro, RJ, Brasil
}

This paper describes patterns of infestation with Tunga penetrans $(L ., 1758)$ within the poor community of Araruama municipality, State of Rio de Janeiro, Brazil, assessed by the number of persons and domestic animals parasitized. The overall prevalence of infestation was 49.2\% (211 parasitized hosts) of the 429 examined. Humans $(p<0.01)$ and dogs $(p<0.01)$ were the most important hosts with $62.6 \%$ and $35.6 \%$ respectively. Dogs were considered as the potential infestation source to humans. Considering sex and age groups, both measures showed a significant difference ( $p<0.01)$ : female $(62.2 \%$ infested of 143 examined) and male $(43.9 \%$ infested of 98 examined). All age classes were found infested with significant difference $(G=42.5 ; p<0.01)$ and most of the infestation occurred in children in the 0-9-year old category (27.3\%). In contrast and based on mean of chigoe burden per person, the parasitic intensity was significantly higher on male than on female in all age categories, except for the $50+(H=27.1 ; p<0.01)$ and decreasing with the increase of age $\left(\chi^{2}=69.7, A=-124.6, p<0.01\right)$. Growing urbanization, improved housing and sewage systems, use of appropriate footwear, examination of the feet principally in young children, antitetanus prophylaxis and reduction of stray dogs population are the major prophylactic methods recommended.

Key words: Siphonaptera - tungiasis - Tunga penetrans - prevalence - host preferences - epidemiology - Rio de Janeiro - Brazil

Tungiasis is caused by the infestation with the female flea Tunga penetrans (L., 1758); this ectoparasite is a small flea of about $1 \mathrm{~mm}$ in length (Hopkins \& Rothschild 1953, Oliver-Llull et al. 1997). The larva of first instar emerges on the 3rd to 4th day after the egg is laid and the pupation occurs between the 10th and 18th day (Hicks 1930). Larvae are found in several kinds of soil, although dry and sandy ground seems to be better for their development. Male and female are hematophagous, male is a parasite, rather of free live but the female penetrates into the dermis of the host causing an intense inflammatory reaction named "neosoma" (Linardi 1998). There are various popular designations for the flea - e.g. jigger, chigoe, nigua and bicho-de-pé - and they indicate that tungiasis has long been a common disease in many parts of the tropics (Mashek et al. 1989, Burke et al. 1991).

According to Heukelbach et al. (2001), the first author to mention the ectoparasite was Gonzalez Fernandez de Oviedo y Valdes. In 1525, he noted that Spanish conquerors in Haiti frequently suffered from the disease (Gordon 1941, Hoeppli 1963). Originally, the flea only occurred

This work was supported by Núcleo de Saúde Coletiva, Secretaria Municipal de Saúde de Araruama, Rio de Janeiro. ${ }^{+}$Corresponding author: Fax: +55-21-2590.3545. E-mail: raicar@ioc.fiocruz.br or raimundowilsoncarvalho@ hotmail.com ${ }^{++}$Research fellow CNPq

Received 2 May 2002

Accepted 25 October 2002 in Latin America and the Caribbean (Sanusi et al. 1989), and it was probably inadvertently introduced into tropical Africa in 1872 by a load of infested ballast sand on board a ship traveling from Brazil to Angola. From there, T. penetrans spread rapidly along the West Coast of Africa, and subsequently throughout the sub-Sahara region and within 20 years reached East Africa and Madagascar. Then, through Indian soldiers that became heavily infested in Africa, the ectoparasite was brought to Bombay and Karachi (Heukelbach et al. 2001).

The main hosts are humans, dogs, cats and pigs (Linardi \& Guimarães 2000), other animals have been found infested such as cattle, sheep, goats, horses, rats, mice, chickens, elephants, monkeys and other wild mammalians (Soria \& Capri 1953, Ruthe 1961, Cardoso 1990, IbanezBernal \& Velasco-Castrejon 1996).

Nowadays T. penetrans is endemic in Latin America, the Caribbean and sub-Sahara Africa; only sporadic occurrence has been reported in America, Asia, Oceania and Europe, mainly in citizens, returning from tropical areas after tourism, and military expeditions (Goldman 1976, Difonzo et al. 1990, Lowry et al. 1996, Veraldi et al. 2000); in Brazil, it occurs with a high prevalence (Matias 1989, 1991). Consequently, the prevalence of tungiasis is poorly known or neglected because it is not a reportable disease (Mckinney \& Mcdonald 2001).

Because of the occurrence of human cases in the Bananeiras community, this study was conducted on request by Araruama municipality, State of Rio de Janeiro, to evaluate an epidemiological survey, pattern and develop possible prophylactics actions to reduce the occurrence of the disease and its impact on the local population's health. 


\section{MATERIALS AND METHODS}

This study was conducted in a locality with 180 dwellings, 800 inhabitants and 138 domestic animals approximately (Prefeitura Municipal de Araruama 1997), situated in Araruama municipality, State of Rio de Janeiro, Brazil. The community's formation has occurred in a spontaneous way during 10 years, through invasions of the public area of the county, constituting a truly poor area, lacking appropriate urban services along the Salgado river margin (Figure).

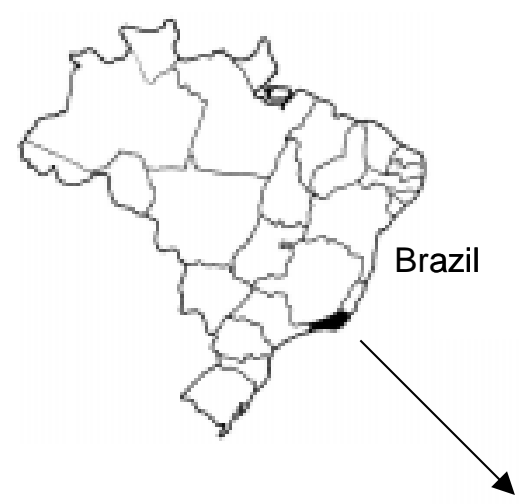

The field procedure was based on residential visits and it was developed between May 1998 and February 1999. The population sample examined was limited to those who were present at the time of the survey. All humans were examined by clinical and macroscopic examination in order to diagnose and to count the flea burdens. All the infested were guided to the local health service to the treatment. The domestic animals were contained than inspected by macroscopic exam. The hosts and in particular the human age and sex profiles of the sample group are showed in Tables I and II.
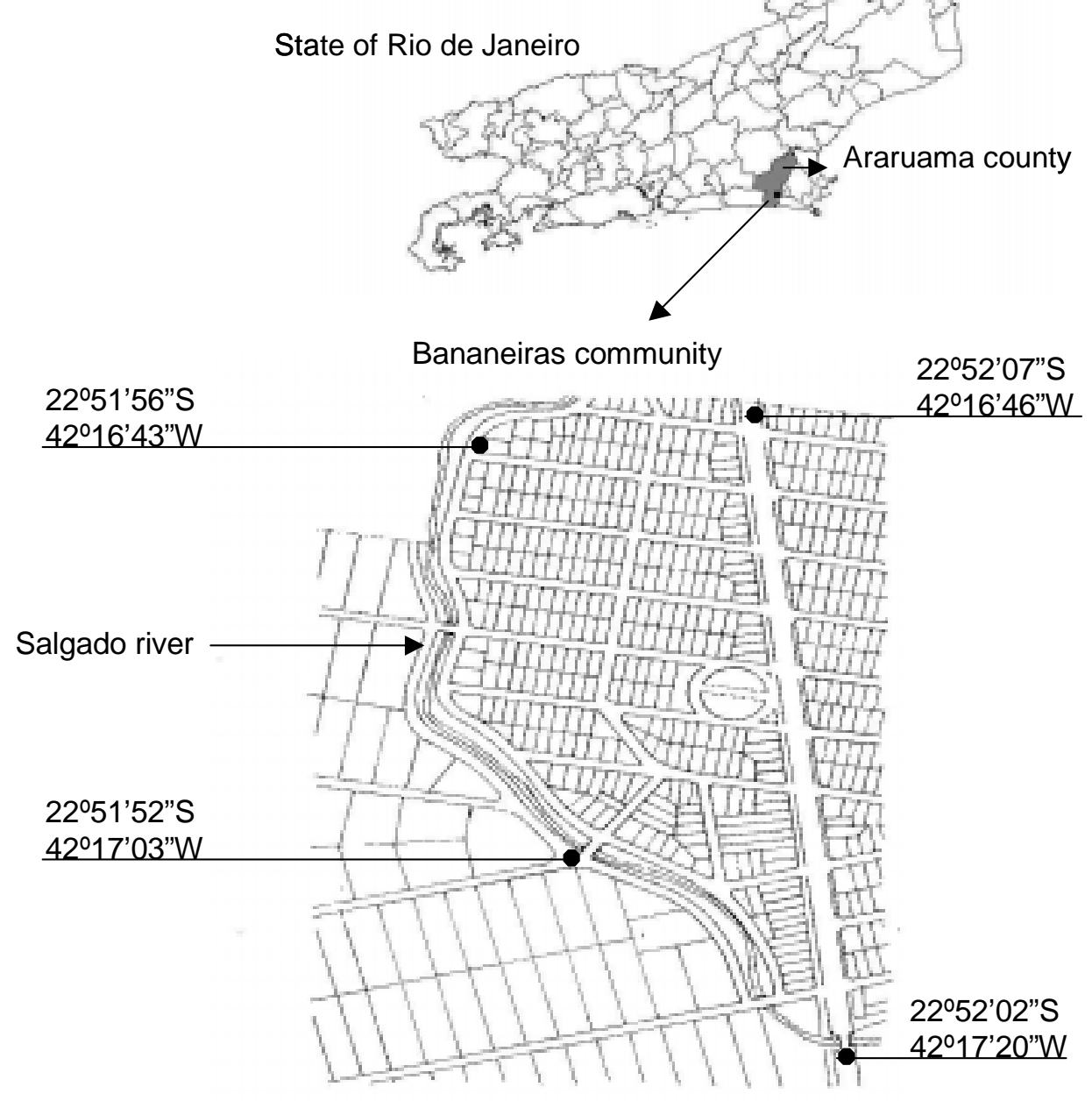

$\overline{88.8} \mathrm{~m}$

Outline map indicating the community of Bananeiras, Araruama district, State of Rio de Janeiro, Brazil. 
The data was analyzed by the BioEstat 2.0 computer program (Ayres et al. 2000), using the chi-square test to determine differences among hosts and human gender, and the $\mathrm{G}$ test for age group infestation, the Kruskal-Wallis test to determine the difference among ranges of parasitic intensity, and the Tendency test to determine the increase or decrease of the prevalence and the parasitic intensity of the infestation according to the age. The statistical significance of the results obtained was tested using a value of $p<0.01$ being considered significant.

\section{RESULTS AND DISCUSSION}

According to the local authorities, the population was of 800 inhabitants, distributed in 180 families, and of approximately 138 domestic animals (Prefeitura Municipal de Araruama 1997). However, it is important to point out that the human population found in this investigation was smaller (715 people in 167 families) and the one of domestic animals was larger (188 animals). The number of humans and domestic animals inspected in the community is reported in Table I. This study has confirmed the presence of $T$. penetrans infestation, widely distributed throughout the locality among various hosts. The overall prevalence was of $49.2 \%$ (211 infested hosts) of 429 examined. Soria and Capri (1953), Ruthe (1961), Cardoso (1990) and Linardi (1998) consider, unlike other species of the same genus, T. penetrans a promiscuous ectoparasite in relation to hosts. According to the present manuscript, the main hosts described in decreasing order of prevalence and importance were humans, dogs, pigs and cats, in agreement with Linardi and Guimarães (2000). Infestation was considerably more prevalent in humans $(62.6 \%)$, with $54.8 \%$ (132 infested individuals) of 241 examined $\left(\chi^{2}\right.$ $=6.8 ; \mathrm{p}<0.01)$ and in dogs (35.6\%) with 61\% (75 infested dogs) of 123 examined than in other animals. Exclusively between humans and dogs, both measurements showed non-significant differences in infestation levels $\left(\chi^{2}=1.27\right.$; $\mathrm{p}>0.01$ ), otherwise among domestic animals, the dog prevalence of infestation was significantly higher $\left(\chi^{2}=\right.$
52.4; $\mathrm{p}<0.01$ ) and highest to that one previously reported by Costa et al. (1990) (Table I). This finding clearly shows that dogs would represent the potential infestation source to humans, in concordance with Rietschel (1989) who suggested that the infestation on man is supported by a large population of stray dogs, and with Heukelbach et al. (2001) who recommended the control of the population and the treatment of infested dogs in order to reduce human parasitism. In spite of this, Oliver-Llull et al. (1997) indicated pigs as the main host to determine the infestation on human community. The infestation on pigs and cats was low $(0.9 \%)$ and individually the prevalence on pigs $(16.6 \%)$ was more important than on cats $(7.7 \%)$ (Table I).

Analyzing the human infestation, 241 (33.7\% of the 715 inhabitants) people were examined and 132 cases were found, representing a prevalence of $54.8 \%$ (Table II). This finding is higher than others in different tropical and subtropical regions (Ejezie 1981), but lower to the one demonstrated by Matias (1991) in two municipalities, in the State

\section{TABLE I}

Hosts prevalence of Tunga penetrans infestation in the community of Bananeiras, Araruama district, State of Rio de Janeiro, Brazil, from May 1998 to February 1999

\begin{tabular}{lcrcc}
\hline & Total & \multicolumn{3}{c}{ Positive } \\
\cline { 3 - 5 } Hosts & examined & No. & $\%$ & $(\%)$ \\
\hline Humans & 241 & 132 & 62.6 & 54.8 \\
Dogs & 123 & 75 & 35.6 & 61 \\
Pigs & 12 & 2 & 0.9 & 16.6 \\
Cats & 24 & 2 & 0.9 & 7.7 \\
Horses & 8 & - & - & - \\
Chicken & 21 & - & - & - \\
(domestic fowl) & & & & \\
\hline Total & 429 & 211 & 100 & 49.2 \\
\hline
\end{tabular}

$\%$ : prevalence among differents species; $(\%)$ : prevalence in the species

TABLE II

Human age-group and sex distribution of Tunga penetrans infestation in the community of Bananeiras, Araruama district, State of Rio de Janeiro, Brazil, from May 1998 to February 1999

\begin{tabular}{|c|c|c|c|c|c|c|c|c|c|}
\hline \multirow{2}{*}{$\begin{array}{l}\text { Age } \\
\text { group }\end{array}$} & \multicolumn{3}{|c|}{ Male } & \multicolumn{3}{|c|}{ Female } & \multicolumn{3}{|c|}{ Total } \\
\hline & Examined & Infested & $\%$ & Examined & Infested & $\%$ & Examined & Infested & $\%$ \\
\hline $\begin{array}{l}0-9 \\
(\%)\end{array}$ & 36 & $\begin{array}{l}11 \\
30.6\end{array}$ & 25.6 & 42 & $\begin{array}{l}25 \\
59.5\end{array}$ & 28.1 & 78 & $\begin{array}{l}36 \\
46.2\end{array}$ & 27.3 \\
\hline $\begin{array}{c}10-19 \\
(\%)\end{array}$ & 28 & $\begin{array}{l}18 \\
64.3\end{array}$ & 41.9 & 23 & $\begin{array}{l}16 \\
69.6\end{array}$ & 18 & 51 & $\begin{array}{l}34 \\
66.7\end{array}$ & 25.7 \\
\hline $\begin{array}{c}20-29 \\
(\%)\end{array}$ & 11 & $\begin{array}{c}6 \\
54.5\end{array}$ & 13.9 & 31 & $\begin{array}{l}19 \\
61.3\end{array}$ & 21,3 & 42 & $\begin{array}{l}25 \\
59.5\end{array}$ & 18.9 \\
\hline $\begin{array}{c}30-39 \\
(\%)\end{array}$ & 11 & $\begin{array}{c}6 \\
54.5\end{array}$ & 13.9 & 19 & $\begin{array}{l}16 \\
84.2\end{array}$ & 18 & 30 & $\begin{array}{l}22 \\
73.3\end{array}$ & 16.7 \\
\hline $\begin{array}{c}40-49 \\
(\%)\end{array}$ & 9 & $\begin{array}{c}2 \\
22.2\end{array}$ & 4.7 & 17 & $\begin{array}{c}9 \\
52.9\end{array}$ & 10.1 & 26 & $\begin{array}{l}11 \\
42.3\end{array}$ & 8.3 \\
\hline $\begin{array}{l}50+ \\
(\%)\end{array}$ & 3 & - & - & 11 & $\begin{array}{c}4 \\
36.4\end{array}$ & 4.5 & 14 & $\begin{array}{c}4 \\
28.6\end{array}$ & 3.1 \\
\hline $\begin{array}{r}\text { Total } \\
(\%)\end{array}$ & 98 & $\begin{array}{l}43 \\
43.9\end{array}$ & 100 & 143 & $\begin{array}{l}89 \\
62.2\end{array}$ & 100 & 241 & $\begin{array}{c}132 \\
54.8\end{array}$ & 100 \\
\hline
\end{tabular}

$\%$ : frequency of infested individuals among age-groups; $(\%)$ : frequency of infested individuals in each age group 
of Rio Grande do Sul, which varied from 43.7 to $87.5 \%$ in urban area and from 87.5 to $100 \%$ in agricultural zones.

The prevalence of tungiasis stratified according to sex and age group is shown in Table II. The infestation was consistently higher on female $(62.2 \%, 89$ infested of 143 examined). Than in male $(43.9 \%, 43$ parasitized of $98 \mathrm{ex}-$ amined), this result disagrees with that obtained from five communities in South-Western Trinidad, West Indies, where the infestation was prevalent on males than on females (Chadee 1998). The distribution of the prevalence by age categories, demonstrated that all age classes were found parasitized, as observed by Chadee et al. (1991), showing differences among them (number infested, $\mathrm{G}=$ $42.5 ; \mathrm{p}<0.01$ ). The majority of cases occurred in the $0-9$ year-old age class (27.3\%). Although present data are lower to those up to $41.5 \%$ reported in Nigerian primary school children by Mashek et al. (1997), it is one of the factors, which probably justifies the school evasion observed in this locality (Prefeitura Municipal de Araruama 1997) (Table II). The low prevalence observed in age groups above 40 years are in conformity with some authors, who assume the importance of immediate extraction after penetration of the ectoparasite or acquired immunity, and the increasing keratinization of the skin of the feet in addition to the more frequent use of shoes, thus presenting a stronger physical barrier to penetration by the female fleas (Chadee 1994). Only the 10-19 year-old age class had a higher prevalence among males, in all other age categories females had a higher rate of infestation than males.

Characteristic and commonest sites of infestation are toes, particularly peri and subungual folds, interdigital spaces, sole and heel (Mashek et al. 1997). Other possible sites of infestations are legs, knees, thighs and hands (Mckinney \& Mcdonald 2001). Most infestations were confined to the foot and toe (81.8\%), as reported by Douglas-Jones et al. (1995), however the ectoparasite was still found on legs and knees (14.4\%), buttocks (3\%) and even on the head $(0.8 \%)$. This result is in agreement with Veraldi and Schianchi (1999), who comment that infestations on knees, buttocks and head are rare, but indicate the seriousness of the infestation.

In total, 449 chigoe burdens were recovered from the 132 individuals with mean intensity (arithmetic mean) equal to 3.4 chigoe burdens per person. In addition, and to establish a parameter for the mean intensity observed in this region, three levels were considered, low (range 1-3 fleas), moderate (range 4-6 fleas) and severe infestation (equal or more than 7 fleas per persons), with the chisquare among the three levels being significantly high $(\mathrm{p}<0.01)$. The low infestation was found on $89(67.4 \%)$ people with $154(34.3 \%)$ fleas recovered, while the moderate on $28(21.2 \%)$ with $136(30.3 \%)$. The most heavily parasitized were $15(11.4 \%)$ individuals with 159 (35.4\%) parasites recovered. The age range of these heavily infested individuals was short, from 3 to 19 years old. The major amplitude (14 fleas) was recovered from four male children belonging to the 0-9 year-old age category and two other from the 10-19 year-old age categories. The parasitic intensity or mean intensity of infestation decreased with the increase of age $\left(\chi^{2}=69.7, \mathrm{~A}=-124.6, \mathrm{p}<0.01\right)$, showing significant differences (Kruskal Wallis, $\mathrm{H}=27.1$; $\mathrm{p}<0.01$ ) between the mean of different age groups and the rates of parasitic intensity, indicating children as the main victims of tungiasis (Table III). This is clear, since the majority of children of that community walked barefoot most of the time. In contrast with the overall prevalence, where the infestation was more important on females, the mean intensity was significantly higher on males than in females, in all age categories, except for the above 50 years old. This sex difference presumably reflects differences in environmental exposure rather than in susceptibility, just as described by Arene (1984). The highest mean intensity was observed in the male 0-9 year-old age category (9.8 per individual). Chadee et al. (1991) found the difference of the mean intensity among male and female to be almost twice the number of fleas detected per subject, in opposition to that found in Bananeiras that was of almost three per male to that of one per female (Table III).

A preliminary entomological survey developed in that township had indicated that $14 \%$ of the researched houses with index cases had been infested by $T$. penetrans (Carvalho et al. 1998), associating these results with that demonstrated in Table III, it is quite possible that the transmission of sand fleas occurs mainly indoors and in peridomiciliary area and probably depends not only on walking barefoot but also on the duration of exposure to infested areas and reservoir hosts.

The population studied lives in a poverty-stricken community, characterized by insufficient or non-existent sanitation with unpaved streets, houses without paved floors, domestic animals raised irregularly, especially dogs and pigs and the absence of domestic trash collections. The people occupied the region after migratory movements and consequently the impact of disordered occupation influenced the local sanitary condition, moreover animals also start to be infested and therefore, contributed to magnification of the sand flea distribution in this area. In conclusion, tungiasis is a disease of the poor as observed by Heukelbach et al. (2001) and according with reported in State of Rio Grande do Sul by Matias (1989).

Tungiasis is usually a self-limiting, uncomplicated infestation results in pain, swelling, tenderness and some limitation in mobility, but there is a potential for secondary infestations. Ultimately, the risk of severe morbidity or mortality from tungiasis depends on the occurrence of secondary infestation, which may follow attempts to extract the flea (Mckinney \& Mcdonald 2001). It is a consensus among local inhabitants and health agents that tungiasis is one of the most important health problem in that locality. During interviews, the physicians declared that there were some cases in which the hypothesis of amputation of a lower limb was studied but not carried out, but, in general, complications were uncommon. According to them when super-infestations occurred, they were mainly caused by Staphylococcus aureus and not due to Gram-negative bacteria as gangrene or tetanus. In Congo, $25 \%$ of the cases of tungiasis developed tetanus (Obengui 1989). Litvoc et al. (1991), during a study of epidemiological aspects of tetanus in the State of São Paulo, Brazil, have detected $18.3 \%$ of cases with tungiasis. 


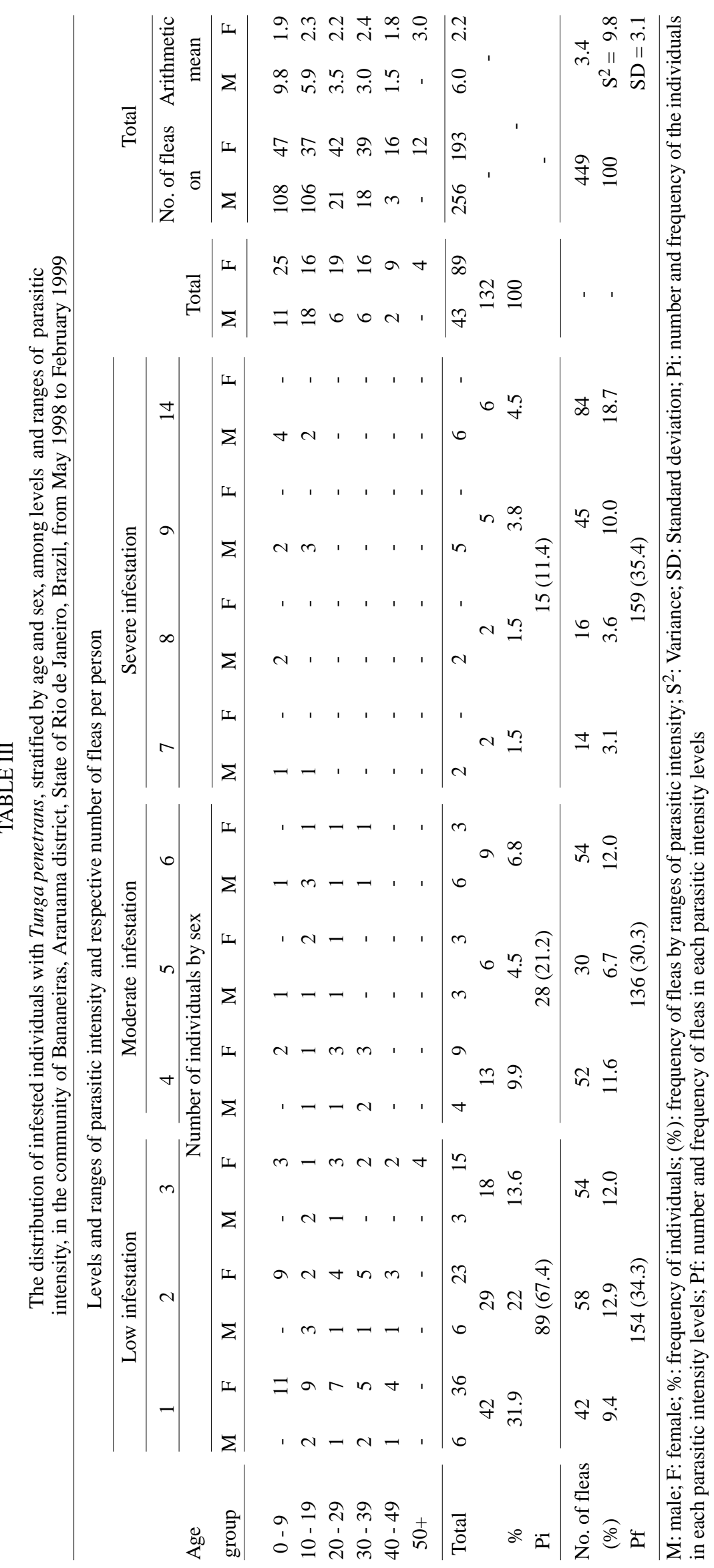


Clostridium tetani has been isolated from flea in Costa Rica where 250 fatal cases were attributed to tungiasis (Lowry et al. 1996).

The prophylactic methods suggested by the laboratory staff, were the ones habitually recommend by Ministério da Saúde (1994), Rozendaal (1997), Veraldi et al. (2000), Heukelbach et al. (2001) and Linardi (2001), consisting in actions on the environment such as urbanization with pavements of streets, construction of sewage systems and improved housing; actions on humans, as daily examination of the feet, mainly in young children, use of appropriate footwear; treatment of single parasites through extraction with a splinter forceps, topical application of an antibiotic, to avoid secondary infestations and the antitetanus prophylaxis must be employed as routine, principally in reached areas; actions on domestic animals: treatment by feet bathing of infested animals with organophosphorous and carbamate insecticide (neguvon and propoxur respectively), control or reduction of stray dog population and appropriate management husbandry of domestic swine.

So, proceeding the recommendation of Rietschel (1989), during the anti rabies' campaign all dogs and cats were treated with subcutaneous injection of ivermectin $(0.2 \mathrm{mg} / \mathrm{kg}$ body weight $)$.

\section{ACKNOWLEDGMENTS}

To the staff of the Health Secretary of Araruama, to Deivone Pinheiro de Oliveira, Rosane de Azevedo Campos and Márcio de Andrade Assumpção. To Maria Cristina Mullins for the revision of the text.

\section{REFERENCES}

Arene FO 1984. The prevalence of sand flea (Tunga penetrans) among primary and post-primary school pupils in Choba area of the Niger Delta. Public Health 98: 282-283.

Ayres M, Ayres Jr. M, Ayres DL, Santos AS 2000. BioEstat 2.0. Aplicação Estatística nas Áreas das Ciências Biológica e Médica, Sociedade Civil Mamirauá, Brasília, 272 pp.

Burke WA, Jones BE, Park HK, Finley JL 1991. Imported tungiasis. Int J Dematol 30: 881-883.

Cardoso 1990. Tunguíase. An Bras Dermatol 65: 29-33.

Carvalho RW, Barbosa-Silva SC, Correia-Gomes DSF, SerraFreire NM 1998. Tungíase em Araruama: inquérito epidemiológico animal. Anais do VII Seminário de Zoonoses e Animais Peçonhentos, Guarapari, 55 pp.

Chadee DD 1994. Distribution patterns of Tunga penetrans within a community in Trinidad, West Indies. J Trop Med Hyg 97: 167-170.

Chadee DD 1998. Tungiasis among five communities in SouthWestern Trinidad, West Indies. An Trop Med Parasitol 92: 107-113.

Chadee DD, Forlonge E, Naraynsingh C, Lê Maitre A 1991. Distribution and prevalence of Tunga penetrans in coastal south Trinidad, West Indies. Trans R Soc Trop Med Hyg 85: 549 .

Costa JO, Guimarães MP, Lima WS, Lima EA 1990. Frequiência de endo e ecto parasitos de cães capturados nas ruas de Vitória, ES, Brasil. Arq Bras Med Vet Zootec 42: 451-452.

Difonzo EM, Canclilheri AG, Tavhi E, Petrini N 1990. Tungiasi: rara conseguenza del fascino dell'esotico? G Ital Dermatol Venereol 125: 519-520.

Douglas-Jones AG, Llwelyn MB, Mills CM 1995. Cutaneous infestation with Tunga penetrans. Br J Dermatol 133: 125-
127.

Ejezie GC 1981. The parasitic diseases of school children in Lagos State, Nigeria. Acta Trop 38: 79-84.

Goldman L 1976. Tungiasis on travelers from Tropical Africa. Jama 236: 1386.

Gordon RM 1941. The jigger flea. Lancet 2: 47-49.

Heukelbach J, Oliveira FAZ, Hesse G, Feldmeier H 2001. Tungiasis: a neglected health problem of poor communities. Trop Med Int Health 6: 267-272.

Hicks EP 1930. The early stages of the jigger, Tunga penetrans. Ann Trop Med Parasitol 24: 575-586.

Hoeppli R 1963. Early references to the occurrence of Tunga penetrans in Tropical Africa. Acta Trop 20: 143-152.

Hopkins GHE, Rothschild M, 1953. An Illustrated Catalogue of the Rothschild Collection of Fleas (Siphonaptera) in the British Museum (National History), British Museum Natural History, London, p. 36-69.

Ibanez-Bernal S, Velasco-Castrejon O 1996. New records of human tungiasis in Mexico (Siphonaptera: Tungidae). J Med Entomol 33: 988-989.

Linardi PM 1998. Tungíase: uma pulga diferente que provoca um problema persistente. Vetores \& Pragas 2: 19-21.

Linardi PM 2001. Pulgas. In CB Marcondes, Entomologia Médica e Veterinária, Atheneu, São Paulo, p. 157-181.

Linardi PM, Guimarães LR 2000. Sifonápteros do Brasil, Museu de Zoologia USP/Fapesp, São Paulo, 291 pp.

Litvoc J, Leite RM Katz G 1991. Aspectos epidemiológicos do tétano no Estado de São Paulo, SP, Brasil. Rev Inst Med Trop São Paulo 33: 477-484.

Lowry MA, Ownbey JL, McEvoy PL 1996. A case of tungiasis. Mil Med 161: 128-129.

Mashek H, Licznerski B, Pincus S 1997. Tungiasis in New York. Int J Dematol 36: 276-278.

Matias RS 1989. Epidemia de tungíase no Rio Grande do Sul. Rev Soc Bras Med Trop 22: 137-142.

Matias RS 1991. Verificação da eficácia de diferentes inseticidas no controle ambiental de Tunga penetrans (L., 1758). Rev Soc Bras Med Trop 24: 31-36.

Mckinney P, Mcdonald LC 2001. Tungiasis. Med J 2: 3-10.

Ministério da Saúde 1994. Controle da Peste - Normas Técnicas, Fundação Nacional de Saúde, Brasília, 124 pp.

Obengui 1989. Tungiasis and tetanus at the University Hospital Center in Brazzaville. Dakar Med 34: 44-48.

Oliver-Llull M, Alfonzo RP, García L 1997. Epidemiologia de la Tunga penetrans en Venezuela. Dermatol Venez 35: 99105.

Prefeitura Municipal de Araruama 1997. Histórico da Tungíase na Comunidade de Bananeiras, Araruama, Núcleo de Saúde Coletiva, Secretaria Municipal de Saúde, Araruama, 4 pp.

Rietschel W 1989. Beobachtungen zum Sandfloh (Tunga penetrans) bei Humanssch und Hund in FranzosischGuayana. Tierarztliche Prax 17: 189-193.

Rozendaal JA 1997. Vector Control - Methods for Use by Indiviuals and Communities, World Health Organization, Geneve.

Ruthe H 1961. Fussleiden der Elefanten. Wssenschaftliche Zeitschrift der Humbldt- Universitä zu Berlin, MathematischNaturwissenschaftliche Reihe 10: 474-514.

Sanusi ID, Brown EB, Shepard TG, Grafton WD 1989. Tungiasis: report of one case and review of 14 reported cases in the United States. J Am Acad Dermatol 20: 941944.

Soria MF, Capri JJ 1953. Tetanos y 'pique'. Prensa Med Argent 40: 4-11.

Veraldi S, Schianchi R 1999. Tungiasis. Eur J Dermatol 9: 5759.

Veraldi S, Carrera C, Schianchi R 2000. Tungiasis has reached Europe. Dermatology 201: 382. 